\title{
TARİHI YAPILARDA MEKANSAL BELLEĞİN KORUNMASI: İZMIT SEKA SELÜLOZ VE KAĞIT FABRİKASININ DÖNÜŞÜMÜ
}

\author{
Hakan ÇAKIR (hknckr.1989@hotmail.com) \\ Beykent Üniversitesi Fen Bilimleri Enstitüsü, İ̧ Mimarlık Tezli, Yüksek Lisans \\ Öğrencisi, İstanbul, Türkiye
}

Bilge YILDIRIM GÖNÜL (bilgeyildirimgonul@gmail.com) Beykent Üniversitesi, Mühendislik-Mimarlık Fakültesi, İç Mimarlık Bölümü, Istanbul, Türkiye

\section{ÖZET}

Tarihi yapılar inşa edildikleri zamanda başlayan belleksel gelişimini kullanıldıkları sürece devam ettirirler. Mekan ve bellek ilişkisi kentsel, yapısal ve mekansal göstergeler üzerinden kurulur. Kullanarak koruma belleğe ilişkin göstergelerin açığa çıkarılması ve geçmiş ile gelecek arasındaki bilgi ağının sürdürülmesi için bir firsattır. Kullanılmayan tarihi yap1 ya da çevrelerde belleğe ilişkin göstergeler zaman içinde yok olabilir.

Mekansal bellek, göstergeler üzerinden okunarak ortaya çıkar. Göstergelerin korunması mekansal bellek için önemli olduğu kadar yapıların tarihsel ve kültürel süreklilikleri için de gereklidir. Nitekim tarihi yapıların sahip olduğu değerler göstergelerle aktarılır. Bu bakımdan mekansal göstergelerin üzeri kapatılmamalı ya da yok edilmemelidir.

Tarihi yapılarda mekansal belleğin korunmasını konu alan bu çalışmada; ilk olarak mekan ve bellek ilişkisi kurulmaya çalışılmıştır. Ardından tarihi yapılardaki müdahale biçimleri mekansal belleğin korunması açısından irdelenerek, SEKA 1 Nolu Kağıt Fabrikasının dönüşümü konu kapsamında örnek yap1 olarak incelemeye alınmıştır. Sonuç olarak; yeniden işlevlendirilen tarihi yapıların korunmasında mekansal belleğin önemli bir faktör olduğu ve bunun göstergeler aracılığıyla sürdürülmesi gereği ortaya çıkarılmıştır.

Anahtar Kelimeler: Tarihi yapı, koruma, yeniden işlevlendirme, yeniden kullanım, İç mekan, mekan, mekansal bellek, gösterge, SEKA Kă̆ıt Müzesi ve Bilim Merkezi, SEKA Selüloz ve Kă̆ıt Fabrikası. 


\title{
PRESERVATION OF THE SPATIAL MEMORY IN HISTORICAL BUILDINGS: TRANSFORMATION OF IZMIT SEKA CELLULOSE AND PAPER FACTORY
}

Hakan ÇAKIR (hknckr.1989@hotmail.com) Beykent University, Institute of Sciences \& Engineering, M.Sc. Student in Interior Architecture Department, Istanbul, Turkey

Bilge YILDIRIM GÖNÜL (bilgeyildirimgonul@gmail.com) Beykent University, Faculty of Engineering \& Architecture, Interior Architecture Department, Istanbul, Turkey

\begin{abstract}
Historical buildings continue to keep the spatial memory which is activated when they are first built as long as they are used. The relationship between space and memory is established over urban, structural and spatial indicators. Preservation through reuse is an opportunity for revealing the indicators of memory and maintaining the information network between past and future. Memory indicators in unused historical buildings or environments may disappear in time.

Spatial memory is revealed when the aforementioned indicators are interpreted. Preservation of these indicators is as necessary for the historical and cultural sustainability of building as it is significant for spatial memory. This arises from the fact that the value born by historical building is reflected via indicators. In this respect, the indicators should not be concealed or destroyed.

In this study, which focuses on the preservation of spatial memory in historical buildings, the researchers initially endeavor to establish a relationship between space and memory. This is followed by an analysis of the types of intervention on historical buildings in terms of preservation of spatial memory and examination of the transformation of SEKA Paper Factory No. 1 as an example. The study concludes that spatial memory is an important factor in preservation of historical buildings which are given new functions and that it should be maintained via indicators.
\end{abstract}

Keywords: Historical buildings, preservation, refunctionalization, reuse, interior, space, spatial memory, indicator, SEKA Paper Museum and Science Center, SEKA Cellulose and Paper Factory. 


\section{GİRIŞ}

Taşınır ve taşınmaz kültür varlıkları toplumların geçmişe dair izlerini, gelecek nesillere aktaran belgelerdir. $\mathrm{Bu}$ durum taşınmaz kültür varlıklarından olan tarihi yapıların sahip olduğu değerlerin önemini vurgular. Mekansal belleğe ilişkin göstergeler tarihi yapıların sahip olduğu değerleri ortaya çıkaran önemli unsurlardır. $\mathrm{Bu}$ bakımdan mekansal bellek göstergeleri tarihi yapıların korunması ve gelecek kuşaklara sağlıklı aktarılması açısından üzerinde durulması gereken önemli bir konudur.

$\mathrm{Bu}$ çalışmada vurgulandığı gibi; tarihi yapıların sahip oldukları mekansal bellek göstergelerinin korunarak sürekliliğinin sağlanması gerekir. Bu durum tarihi yapıları korumaya ilişkin kararların ve iç mekan tasarım parametrelerinin doğru değerlendirilmesi ile mümkün olabilir. Araştırma kapsamında yeniden işlevlendirilen tarihi yapılarda iç mekan tasarım parametreleri, mekansal bellek göstergelerinin korunması açısından değerlendirilip SEKA Selüloz ve Kağıt Fabrikasının dönüşümü üzerinden incelenmiştir. Elde edilen sonuçlar tarihi yapıların iç mekan açısından korunmasına yönelik değerler oluşturmaktadır.

\section{MEKAN VE BELLEK İLIŞKISİ}

Genel olarak geçmiş deneyimlerin sonraki/şimdiki bir zamanda hatırlanma durumu olan bellek kavramı farklı açılardan pek çok disiplinin ilgi alanı içine girmektedir. Hatırlama eylemi göstergeler üzerinden gerçekleştiğinde "mekan" belleğe ilişkin önemli bir bilgi deposu haline gelmektedir. Bu bilgiler mekansal belleğe ilişkin göstergeler üzerinden okunur.

Geçmişten günümüze kadar şartlar ve koşullar değişse de, insanın duyumsal, deneyimsel olarak algıladığı mekanı bir süre sonra içgüdüsel olarak sahiplenmesi ve aidiyet hissi oluşturması büyük oranda aynı kalmıştır. İnsanın kendi bölgesini oluşturması, 
beraberinde kendi yaşam alanını kurmasını ve tanımlamasını birlikte getirir. İnsan kendi tanımladığı mekanda yaşamaya başladıkça mekana karşı aidiyet duygusu geliştirmeye başlar. Bu yaşanmışlıklar ve anılarla birey kendi mekansal belleğini oluşturur.

Belleğin zamanla ilişkisi kaçınılmazdır. Heidegger'e göre zaman; “...içinde bir şimdi noktasının keyfi olarak saptanabileceği bir şeydir; öyle ki, iki farklı zaman noktasından biri önce diğeri sonrasıdır. Ama zamanın şimdi noktalarından hiçbiri bir diğerine göre ayrıcalıklı değildir. Herhangi bir şimdi noktası, "şimdi" olarak, daha sonraki birinin muhtemel öncesidir; "sonra" olarak da daha önceki birinin sonrasıdır... Öyleyse zaman, aşamaları birbirine göre önce ve sonra ilişkisi içinde olan açılımdır. Her önce ve sonra şimdiye göre belirlenir ki, bu şimdinin kendisi keyfidir.', (Heidegger,1997). Bu görüş, bellek kavramının zamanla ilişkisine dikkat çekmektedir. Bellek zamanın farklı aşamalarında ve bu aşamaların birbirleriyle ilişkili olduğu biçimde ortaya çıkarak şimdiki zamana göre şekillenir.

Huyssen'e göre bellek; “Alg1, deneyim ve hayal edilenlerin birleşimidir. Yaşanılan çağa ve bu çağın bağlamına uzak zamanlara dair imgeler, kişinin imgelemesi sonucu olarak zihinde canlanır. Kişinin yaşadığı zamandan geçmişe ve geleceğe bakabilmesini, eski zamanların imgeleriyle bugün bu imgelere kişinin kendi yorumlarını katarak buluşturan belleğin canlanışıdır.'” (Huyssen,1995; 35). Buna göre, imgenin belleğin oluşumunda önemli bir parametre olduğu ve yaşanılan zamana göre farklılık gösterebileceği söylenebilir.

Bellek kavramının kendi içindeki çalışma şeklini Cevizci şöyle özetlemektedir; "Belleğin oluşumunda ya da anımsama sürecinde üç ayrı durum söz konusudur. Birincisi; daha önce algılanmış olan nesnenin zihinde canlandırılması, bellekte bir imge oluşturması, ikincisi; imgenin, anımsayanın geçmişinin bir parçasını meydana getiren bir nesnenin imgesi, sureti olarak tanınması, üçüncü durum ise; anımsanan nesnenin psikolojik ya da fiziki bir zaman çerçevesi 
içine yerleştirilmesi'" (Cevizci, 1996; 67). Bu görüş bellek kavramının kendi içinde algı, imge ve anımsamaya dayanan psikolojik ya da fiziki bir zaman faktörüne bağlı bir sistemle ilişkisi oluştuğunu gösterir.

Yer-mekan ilişkisi açılanırken, felsefe, antropoloji, sosyoloji, coğrafya ve diğer sosyal bilimlerde bu kavramının nasıl ele alındığının incelenmesi gerektiği gibi yerin fenomonolojik anlamı üzerinde de durulmalıdır. Hançerlioğlu, fenomenolojiyi (olaybilim) "Nesnenin bilgisine ancak özneden varılabileceği savının gerçekleştirildiği ileri sürülen yöntem" şeklinde tanımlamaktadır", (Hançerlioğlu, 2012;166). Bu bakımdan fenomonoloji kavramının farklı kişiler, toplumlar ve kültürler tarafından çeşitlilik gösterebileceği söylenebilir. Başkası için bir anlamı ve değeri olan bir yer, başka biri için sıradan değersiz bir yer olabilir.

Rossi’ye göre yer (locus) kavramı; “'Belirli bir yer ile onun içindeki binalar arasındaki ilişkidir. Aynı zamanda hem tekil hem evrenseldir.' (Rossi, 2006; 93). Buna göre “Locus'” yer - yap1 ilişkisine dayanan olgusal bir durum olarak ortaya çıkar. Yıldırım'a göre "Hem kent, hem de tek yapı için yer seçiminin önemle ele alındığı klasik dönemlerde bu seçim " Genius Loci”" tarafından belirlenmektedir. Toplumda kültürel, geleneksel ve dinsel görüngülerin oluşturduğu zihinsel bir eylem olan "Genius Loci”, kavramı, "Yer'” kavramını da içermektedir (Yıldırım, 1996;27).

Mekan kullanıcının bilgi birikimi, kişisel özellikleri ve yaşam şekli doğrultusunda, algılanır. Bu yüzden kişiden kişiye farklılık gösterir. Yani A kişisinin çok rahat algılayabildiği bir mekanı B kişisi aynı şekilde algılayamayabilir. Bu durumda kullanıcılar üzerinde aynı mekanda ortak yargıya varılamayabilir.

Kullanıcı tarafindan algılanan mekan deneyimlenerek belleğe kodlanır. Kodlama işlemi kişinin duyum ve deneyimlerine göre kısa yahut uzun süreli bellek olarak göstergeler üzerinden mekansal belleğe dönüşür. Belleğe kodlanan mekan, kullanıcı tarafindan 
zihinde imgeye dönüştürülerek aidiyet kazanır. Bir sonraki süreçte olgusal olarak anlam kazanan yer (locus), toplumsal ve kentsel olaylar sonucunda bellekte yerini alır.

"Bilinç demek, bellek demektir" diyen Bergson, sürekli sarılan bir yumağa benzettiği yaşamda üst üste eklenmelerle kişinin belleğinin oluştuğuna vurgu yapmaktadır (Bergson,1998;11). Bir başka deyişle; bireysel bellek yaşam süresince şekillenmektedir. Toplumsal bellek için; "Bireysel hatırlamalara, resmi anma törenlerine, kolektif temsillere, ortak kimliklerin ruhani ve yapıcı özelliklerine gönderme yapmak üzerine tanımlandığ 1 , kişisel tanıklıkta, sözlü tarihte, gelenek ve mitte, dil, sanat ve popüler kültürde konumlandığı söylenmektedir', (Olick, 1999; 336). Bu görüş doğrultusunda, toplumsal belleğin yer yer kültürel bellekle iç içe olup aynı kaynaktan beslendikleri söylenebilir. Kültürel belleğin ilgi alanındaki tarih, gelenek, mitoloji gibi konular toplumsal ve kentsel bellekte de önemli bir yer oluşturur.

\section{TARİHI YAPILARA MÜDAHALE BICÇIMLERININ MEKANSAL BELLEĞIN KORUNMASI KAPSAMINDA İRDELENMESI}

Ayakta kaldıkları sürece korunmaları için tarihi yapılara müdahale etmek gerekebilir. Romantik görüşün savunucularından J. Ruskin The Seven Lamps of Architecture adlı yapıtında "Anıtlarınıza iyi bakın, o zaman restorasyona gerek kalmayacaktır. Zamanında çatıya konulan bir kurşun levha, yağmur oluklarından vaktinde temizlenen birkaç dal ve yaprak, hem çatıyı hem de duvarları büyük hasarlardan koruyacaktır."' (Ruskin,1849;186) diyerek basit onarımların esaslı onarımlara tercih edilmesi gerektiğini vurgulamıştır. Bu durum tarihi yapıların sahip oldukları değerleri yitirmeden korunması açısından önemlidir. Basit biçimde onarılmayarak hasarlar büyüdüğünde tarihi değerler yitirilebilir ya da büyük müdahaleler gerekebilir. Bunlar uzman kişilerce gerçekleştirilmediğinde de tarihi yapı koruma açısından risk altına girebilir. Venedik Tüzüğünde onarımın, 
uzmanlık gerektiren bir iş olduğu, belge ve bilgiye dayalı biçimde yapılarak faraziyenin başladığı yerde de durması gerektiği savunulur. Bütün bunlardan anlaşılmaktadır ki; tarihi yapılarda basit onarımlar, mekansal bellek göstergelerinin sürekliliğinin korunması için tercih edilmesi gereken uygulamalardır.

Mekansal belleğin göstergeler üzerinden okunması tarihi yapılar için önemli değerler oluşturur. Bu açıdan mekansal belleğin yitirilmeden göstergeler üzerinden okunarak sürekliliğinin sağlanması koruma açısından doğru bir yaklaşımdır. Tarihi yapıların korunması için farklı müdahale yöntemleri gerekebilir. Kimi zaman birden çok uygulama birlikte söz konusu olabilir. Renovasyon, rehabilitasyon, konservasyon, rekonstrüksiyon ve taşıma uygulamaları mekansal bellek göstergeleri kapsamında ayrı başlıklar altında incelenmiştir.

\section{Renovasyon uygulamaları mekansal bellek göstergeleri} kapsamında irdelendiğinde; mekandaki belleğe ilişkin göstergelerin sahip olduğu tarihi değerler ön plana çıkar. Fiziki ömrünü sürdüren tarihi bir yap1 yeniden işlevlendirilebilir. Yeniden işlevlendirme aşamasında tarihi değer niteliği taşıyan mekansal bellek göstergelerinin yok edilmemesi veya üstlerinin örtülmemesi gerekir. Aksine bunların açığa çıkarıldığı koruma yaklaşımları mekansal belleğin korunarak sürekliliğinin sağlanması ve yapının tarihi değerini yitirmemesi açısından önemlidir.

Rehabilitasyon uygulamaları mekansal bellek göstergeleri kapsamında değerlendirildiğinde; Feilden'in görüşü dikkat çekicidir. Feilden rehabilitasyonu; "Bir binayı kullanımda tutmaya yönelik, korumanın en iyi yolu olarak görmektedir. Olası strüktürel değişimleri ve modernizasyonu içeren bir uygulama" olarak tanımlar (Feilden,2003;10). Tarihi yapılarda kullanımın devamlılığı mekansal belleğin de sürekliliğini akla getirir. Ancak burada dikkat edilmesi gereken şudur; sağlıklaştırma uygulamaları mekansal belleğe ilişkin göstergelere zarar verilmeden gerçekleştirilmelidir. Aksi takdirde bir süre sonra tarihi yapı değerini yitirebilir. Mevcut 
ya da yeni bir işlevle sağlıklı bir kullanımı destekleyen rehabilitasyon uygulamaları, göstergeler kapatılmadığı ya da yok edilmediği sürece tarihi yapıda mekansal belleğin korunmasına ilişkin olumlu bir yaklaşım olarak değerlendirilir.

Konservasyon uygulamaları mekansal bellek göstergeleri kapsamında irdelendiğinde; fiziksel ve mekansal bütünlük içinde korunan bir yapıya ait belleksel unsurların göstergeler aracılığıyla geleceğe bilgi aktarması açısından doğru bir yaklaşım olarak değerlendirilir. Zira konservasyon, değişiklikten yana bir düşünce değildir.

\section{Rekonstrüksiyon uygulamaları mekansal bellek göstergeleri} kapsamında irdelendiğinde; fiziksel hasarlı olduğu için kısmen ya da tamamen yeniden inşa edilen bir yapıda tarihi değer taşıan izlerin iki farklı etki altında kaldığı görülür. İlk olarak, hasarlı olan kısmi bölüm özgün ya da yeni bir malzemeyle onarılmış olsa da (ki bu onarımın izi belli edilmelidir) tarihi yapının özgün bölümünde mekansal bellek, göstergeler üzerinden okunarak bilgi aktarmaya devam eder. Buradaki müdahale kısmi niteliklidir. İkinci olarak ise; bilgi belge ve çeşitli görseller ile temel izleri referans alınarak tamamı yeniden inşa edilen yapıda mekansal bellek göstergeleri büyük risk altındadır. Yapı tarihi değerini kaybetmiştir. Anı değerinin olmadığı bir mekanda göstergeler yok olduğunda, bellek yitirilmiştir. Geçmişinin birer kopyası şeklinde inşa edilen yapı, bağlamsal olarak o bölgedeki siluetin bir parçası biçiminde toplumsal ve kentsel bellekte yeni bir yer edinebilir.

Taşıma uygulamaları mekansal bellek göstergeleri kapsamında irdelendiğinde; uygulama işleminin yarattığı hasara bağlı olarak olumsuz sonuçlara neden olabileceği düşünülmelidir. Ancak burada taşınan strüktürün malzeme ve yapım tekniğinin niteliği taşıma işleminin başarısını etkileyen bir faktördür. Hafif malzemelerin kullanıldığı sistemlerde taşıma uygulamasıyla mekansal bellek göstergeleri daha az zarar görmektedir. Karadeniz Bölgesinde 
bulunan ahşap yapıların taşıma işlemleri bu açıklama için iyi bir örnektir (Şekil 1).

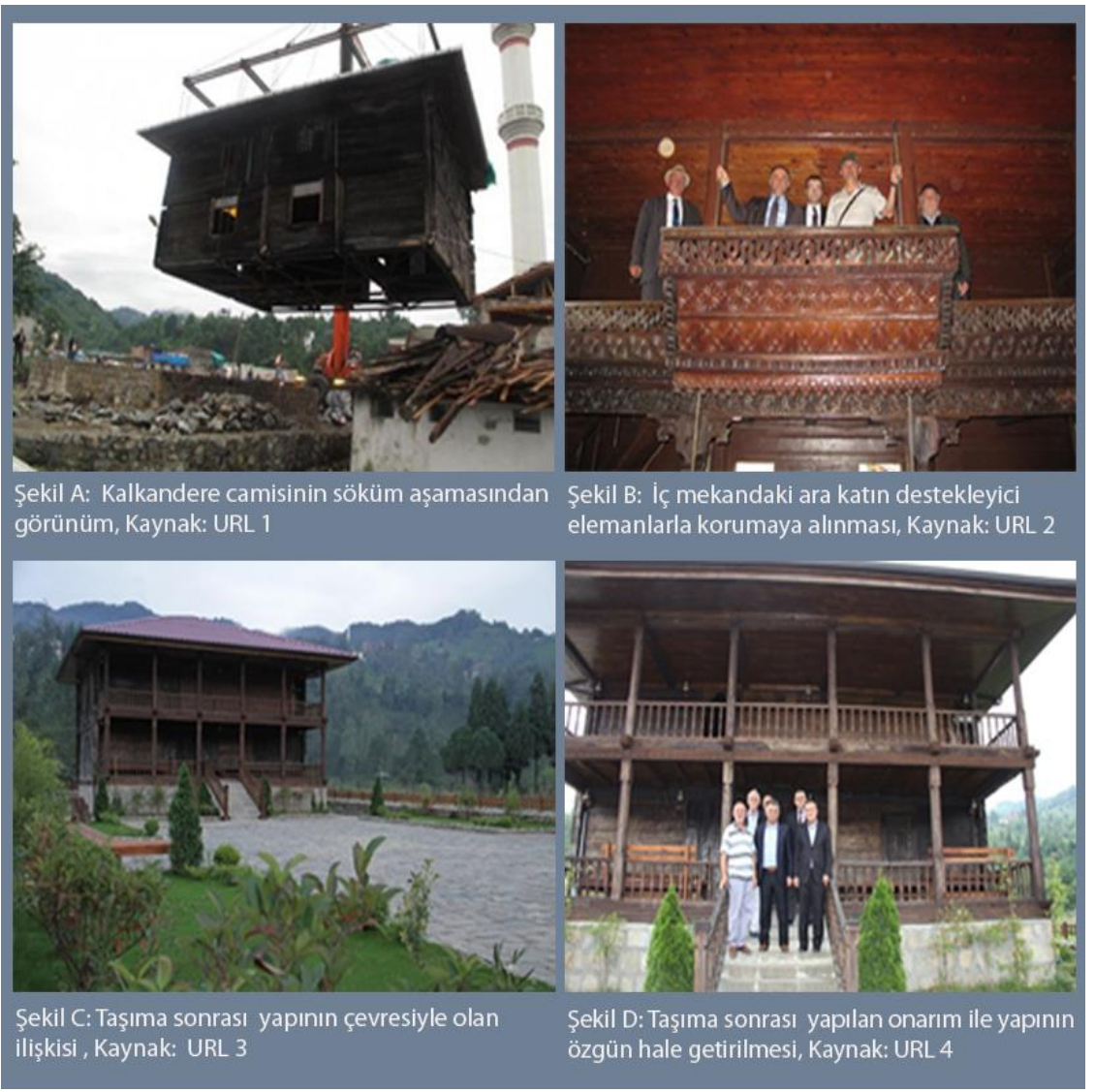

Şekil 1. Kalkandere camisinin taşıma aşamaları

Bazı uygulamalarda rekonstrüksiyon ve taşıma işlemlerinin birlikteliği kısmen korunma durumunu ortaya koyabilir. Strüktürel açıdan sağlıklı olmayan tarihi bir yapının yeniden inşa edilmesi gerektiğinde, mekanda yer alan tarihi nitelikli göstergeler; mobilyalar, kapılar, çini yüzeyler vb. sökülüp ya da yerinden taşınıp, daha sonra tekrar yerine getirildiklerinde varlıklarını sürdürmeye devam ederler. Ancak buradaki varlıkları mekanın özgün bileșenlerinden bağımsız niteliktedir. 


\section{YENIDEN IŞLEVLENDİRILEN TARIHİ YAPILARDA MEKANSAL BELLEĞIN KORUNMASI: SEKA SELÜLOZ VE KAĞIT FABRIKKASI ÖRNEĞİ}

Seka Selüloz ve Kağıt Fabrikası'nın örnek yapı olarak incelendiği bu çalışmada 1 nolu kağıt fabrikası dönüşüm kapsamında ele alınmıştır. 1 nolu kağıt fabrikası SEKA'nın ilk yapısı olması nedeniyle özgünlük, tarihi ve kültürel değer bakımından nitelikli bir örnek olduğundan bu yapı üzerinde analiz çalışması gerçekleştirilmiştir. Yeniden işlevlendirilen tarihi yapılarda mekansal belleğin korunmasına ilişkin parametreler iki başlıkta ele alınmıştır (Tablo 1). İlk olarak, tarihi yapılarda mekansal bellek göstergelerinin sahip olduğu değerler üzerinde durulmuştur. İkinci olarak ise, mekansal bellek göstergelerinin korunmasına ilişkin tasarım parametreleri ele alınmıştır.

Tablo 1. Yeniden işlevlendirilen tarihi yapılarda mekansal belleğin korunmasına ilişkin parametreler

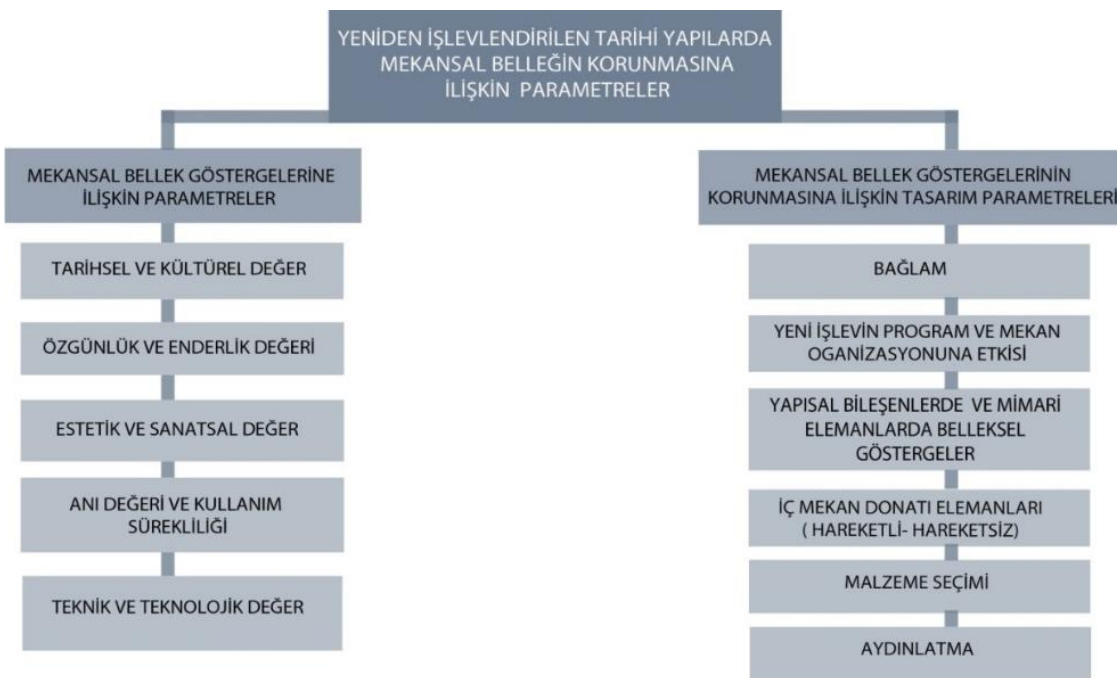

Türkiye'de ilk modern kağıt üretimin gerçekleştirildiği SEKA

Selüloz ve Kağıt Fabrikası ve bulunduğu alan, 8 Kasım 2004'te Özelleştirme Yüksek Kurulu tarafından Kocaeli Büyükşehir Belediyesine devredilmesiyle birlikte, dönüşüm etaplar halinde 
planlanmıştır. İlk etapta, sahil kesiminde bulunan liman bölgesi çağdaş bir parka dönüştürülmüştür. İkinci etapta, fabrika yapılarının yoğunlukta olduğu alanın dönüşümüne geçilmiştir. Üçüncü etapta ise, mülkiyet sorunu olan yapıların projelendirilmesi üzerinde durulmuştur. Çalışmanın bu bölümünde; yeniden işlevlendirilen tarihi bir yapı örneği olan SEKA Selüloz ve Kağıt Fabrikası'nın, Kağıt Müzesi ve Bilim Merkezine dönüşümü, mekansal belleğin korunması kapsamında parametreler üzerinden irdelenmektedir.

Mekansal Bellek Göstergelerine İlişkin Parametreler Açısından SEKA Selüloz ve Kağıt Fabrikasının Dönüşümünün İrdelenmesi, belleğin göstergeler üzerinden okunmasına yönelik değerlerin ortaya konmasını gerektirmiştir.

Tarihsel ve Kültürel Değer: Tarihi yapılar eskilik değeri boyutunda, inşa edildikleri dönemin yaşam biçimlerine, sosyal, kültürel ve ekonomik özelliklerine ilişkin pek çok veriyi taşırlar. Bu yapıların sahip oldukları tarihsel ve kültürel değerler göstergeler üzerinden okunarak sürekliliğini sağlarlar. $\mathrm{Bu}$ nedenle, tarihi yapıların yeniden işlevlendirme sürecinde, tarihsel ve kültürel yönden değer taşıyan mekansal belleğe ilişkin göstergeler özenle korunmalıdir.

Türkiye Cumhuriyetinin kamu eliyle yürütülen sanayileşme kapsamında inşa edilen fabrika komplekslerinden biri olan SEKA Selüloz ve Kağıt Fabrikası tarihsel ve kültürel değer bakımından önemli bir yere sahiptir. 1900'lü yıllarda ülkenin kağıt ihtiyacını karşılamak için kurulmuş olan bu kompleks, Kocaeli bölgesi için anıtsal bir nitelik taşımaktadır. Fabrika bünyesinde kurulan sosyal kulüpler ve çıraklık okulları gibi kente dağılmış haldeki ayrı birimler, SEKA Selüloz ve Kağıt Fabrikasının yer aldığı bölgede halkın belleğini kolektif olarak etkilediği gibi, kentin belleğini de göstergeler üzerinden etkilemiştir. Bu durum, dönüşüm kapsamında 
SEKA Fabrikasının sahip olduğu tarihsel ve kültürel değer taşıyan mekansal bellek göstergelerinin korunmasını gerektirir.

Özgünlük ve Enderlik Değeri: Tarihi bir yap1 sahip olduğu bütün özellikleri ile korunarak günümüze ulaşabilmişse korumanın özgünlük değeri boyutunda önemli bir yere sahiptir. Bu durumda mekansal belleğe ilişkin göstergelerin de zarar görmeden korunduğu düşünülür.

SEKA Selüloz ve Kağıt Fabrikasının, Kağıt Müzesi ve Bilim Merkezine dönüşüm sürecinde mimari ve dönemsel kimliğin yansımaları korunduğu için özgünlük değeri bakımından örnek bir uygulama olarak gösterilebilir. Renovasyon sonrasında mekansal bellek göstergeler aracılığıyla okunabilmektdir. Bu durum yapıda bellek ve iç mekan ilişkisinin korunarak sürdürüldügünü gösterir.

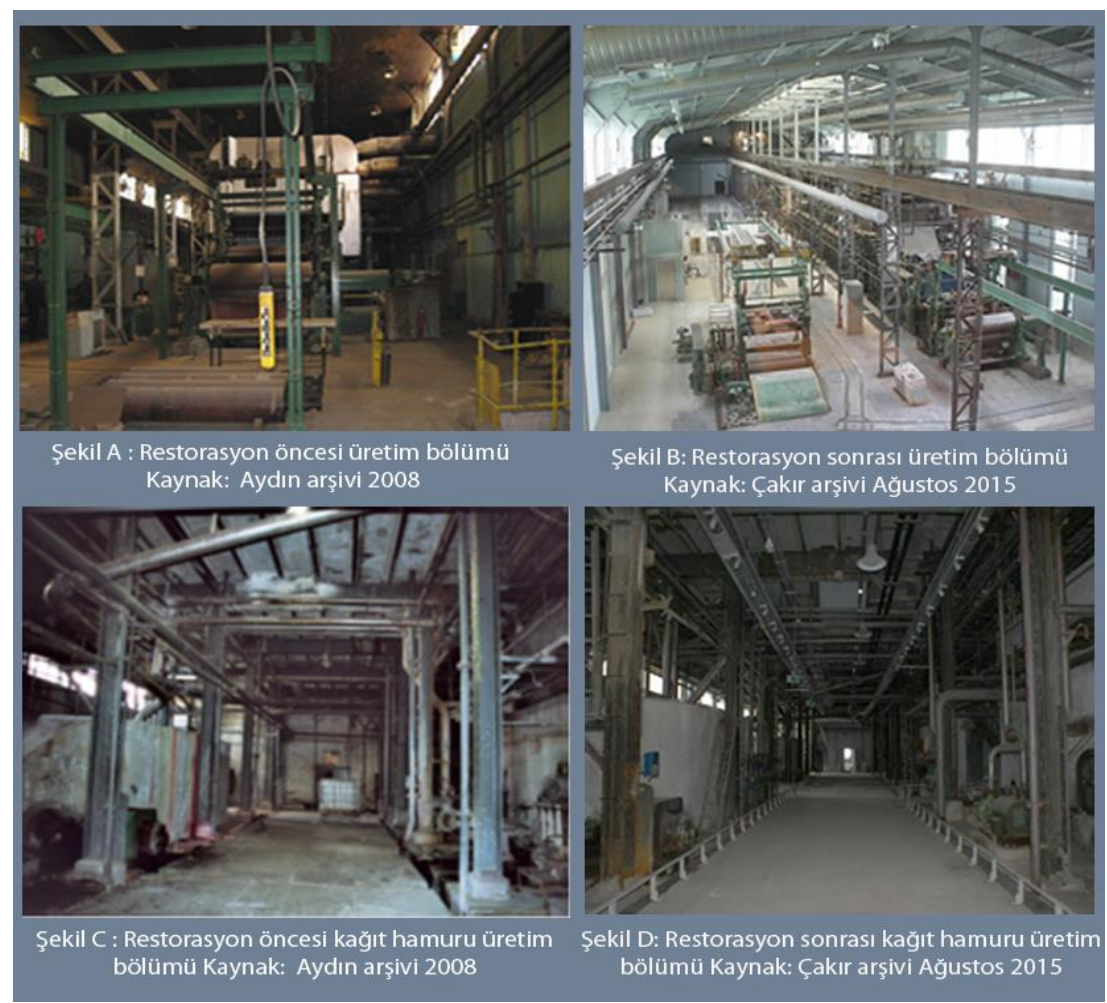

Şekil 2. SEKA Selüloz ve Kağıt Fabrikasının dönüşümünde korunan mekansal bellek göstergeleri 
1 Nolu Kağıt Fabrikasının, dönüşüm öncesi ve sonrası durumu incelendiğinde, üretim bölümünün çalışır vaziyette korunması yapının özgünlük değerinin korunduğunun göstergesidir (Şekil 2). Üretim bölümündeki bu özgünlük değerinin korunması ve dönemsel fabrika ortamının yaşatılması yapının mekansal belleği için oldukça önemlidir. Böylelikle ziyaretçiler kağıt hamuru üretiminin gelişimi hakkında bilgi sahibi olabileceklerdir. Ayrıca bu durum yapının özgünlük değerini de öne çıkarmaktadır.

Estetik ve Sanatsal Değer: Tasarım yaklaşımları, mimari üslup, bezeme ve süsleme özellikleri ile ait oldukları dönemin niteliklerini yansıtan tarihi yapılar estetik ve sanatsal değerlere sahiptir. Bu değerler göstergeler üzerinden okunarak mekansal bellekte yerini alır. Tarihi yapılar fiziksel özelliklerinin yanı sıra sanatsal ve estetik açıdan, mekansal belleğe ilişkin göstergelerle bir bütün olarak değerlendirilmeli ve korunmalıdır.

Kübik ve yalın cepheli bir karaktere sahip olan SEKA Selüloz ve Kağıt Fabrikasındaki yapılar minimalist bir mimari anlayışla tasarlanmıştır. Dönüşüm sürecinde endüstri mirası niteliğindeki özgün mimari kimliğini koruyan bu kompleks, kentsel ve mekansal bellek açısından önemli bilgiler barındırmaktadır (Şekil 3).

Anı Değeri ve Kullanım Sürekliliği: Her bireyin ve topluluğun geçmişte yaşanmış olaylarla ilgili anıları bulunmaktadır. Bu anılar bazı durumlarda yapıyla bütünleşir. Kişinin doğup büyüdüğü ev, köy düğününde tavana sıkılmış mermi izi, iç savaşta duvarları delinen evler, iyi ya da kötü yaşanmışlığı olan anılar iç mekanlarda tarihin cansız tanıklarıdır. Tarihi yapıların kullanımlarının sürekliliği içinde mekansal belleği canlı ve dinamik tutan bu göstergeler, her türlü yenileme ve onarım sürecinde dikkatle ele alınarak korunmalıdır. 


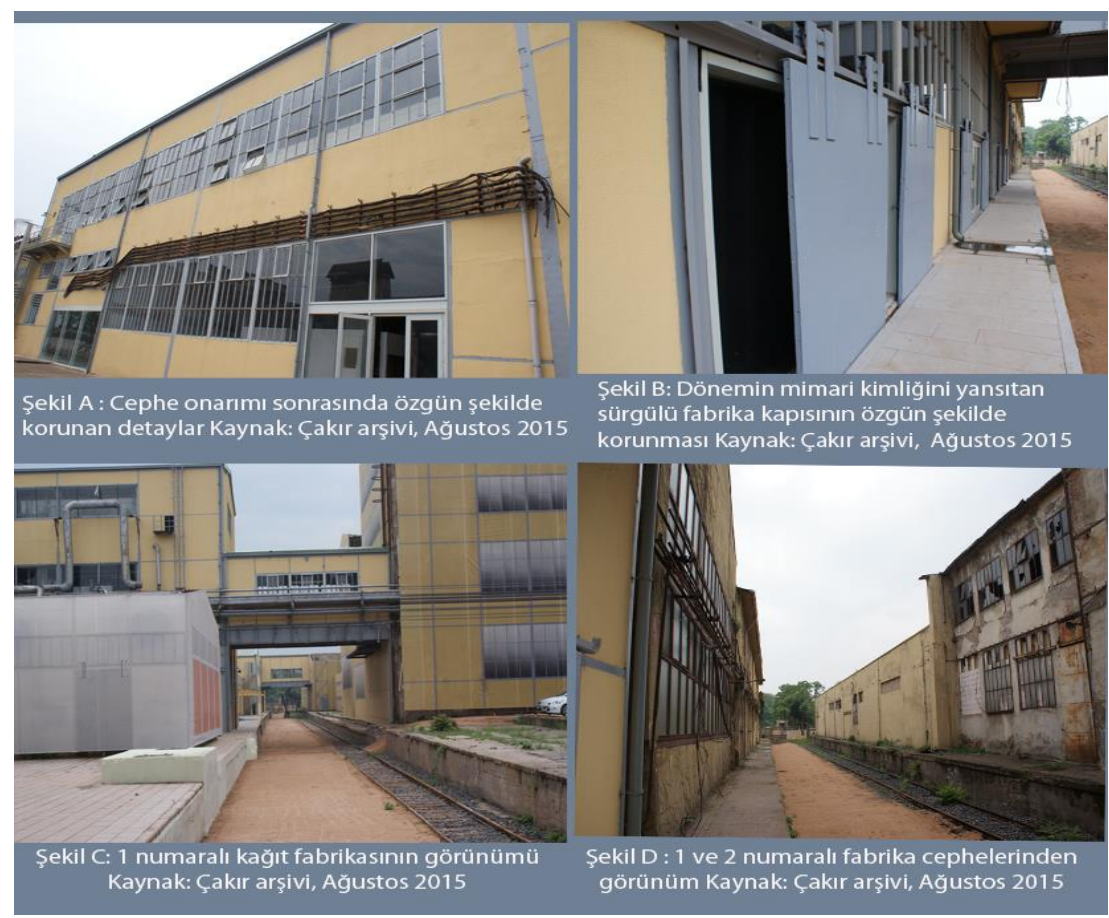

Şekil 3. Onarım sonrası SEKA Selüloz ve Kağıt Fabrikasının cephelerinden görünüm

Cumhuriyet döneminin en köklü fabrika komplekslerinden olan SEKA Selüloz ve Kağıt Fabrikası, kullanım sürekliliği ve anı değeri bakımından toplumun belleğinde yer etmiş bir nirengi noktasıdır. SEKA 1 nolu Kağıt Fabrikasının dönüşümünde, kullanım değeri ve dönemsel fabrika ortamının izlerinin korunarak gösterilmesi, anı ve kullanım sürekliliği bakımından başarılı bir yaklaşımdır (Şekil 4). SEKA bünyesinde bulunan Kağıt Spor Kulübü, çıraklık okulu, dergi yayını ve çeşitli sağlık sendikalarıyla kendi içinde anı ve kullanım sürekliliğini etkileyen parametreler oluşturmuştur. Yerel bir sosyal birlikteliğe yol açan bu durum mekansal açıdan fabrika yapılarına yansımaktadır. 


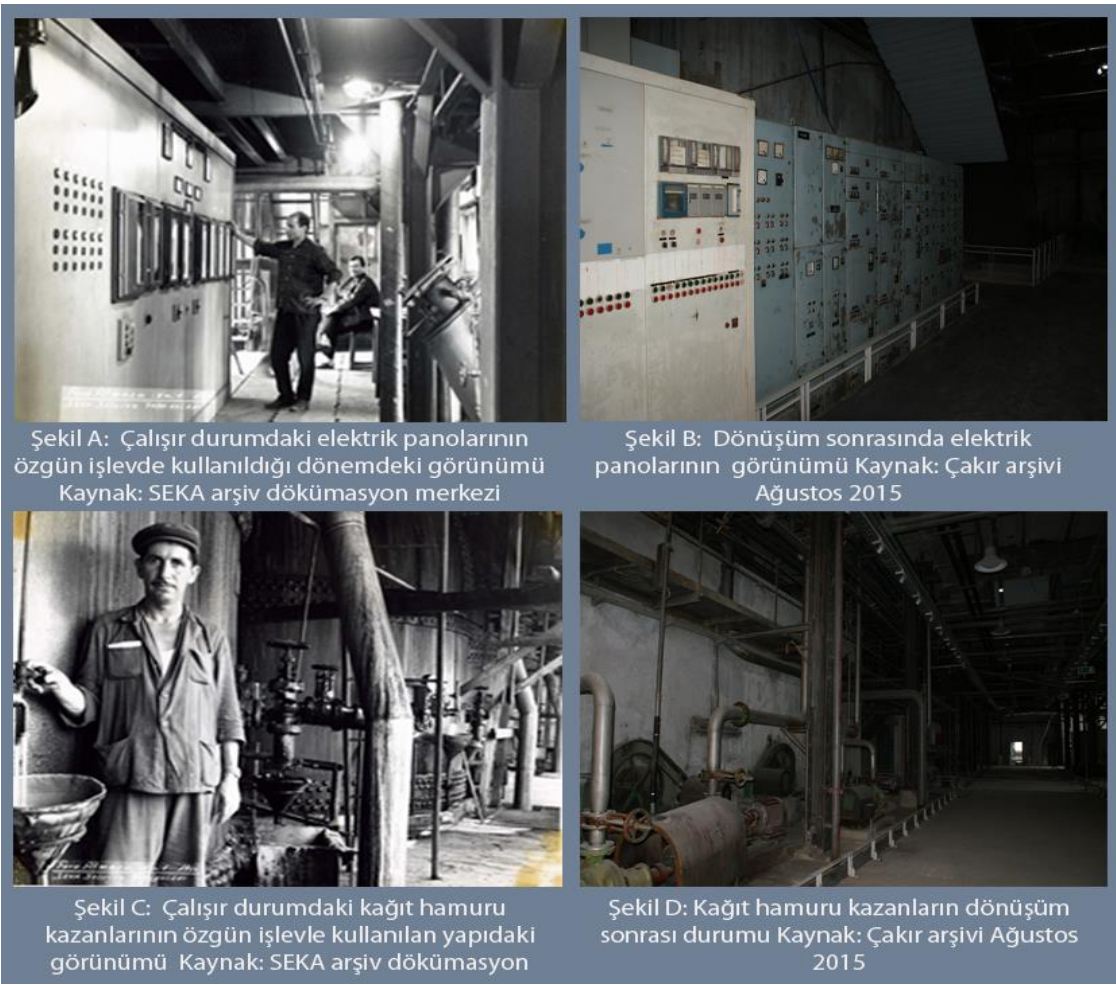

Şekil 4. Anı ve kullanım sürekliliği bakımından SEKA Fabrikasının incelenmesi

Teknik ve Teknolojik Değer: Tarihi yapılar inşa edildikleri dönemin teknolojisi, yapım tekniği ve malzeme bilgisi hakkında bilgiye sahiptirler. $\mathrm{Bu}$ bilgilerin mekansal bellek göstergeleri üzerinden okunarak sürekliliğinin sağlanması, koruma karar ve uygulamalarının dikkate alınmasını gerektirir.

SEKA 1 nolu Kağıt Fabrikası inşa edildiği dönemin kağıt yapım teknolojisi ve tekniğini yansıtan önemli değerlere sahiptir. Endüstriyel mirasın simgelerinden biri olan bu yapı dönüşüm sonrasında özgün makine, vinç, jeneratör ve kontrol panoları gibi mekansal göstergelerin çalışır şekilde korunmasıyla teknik ve teknolojik değerini korumaktadır (Şekil 5). Bu değerler 1şığında mekansal belleğin de korunarak sürekliliği sağlanmaktadır. 


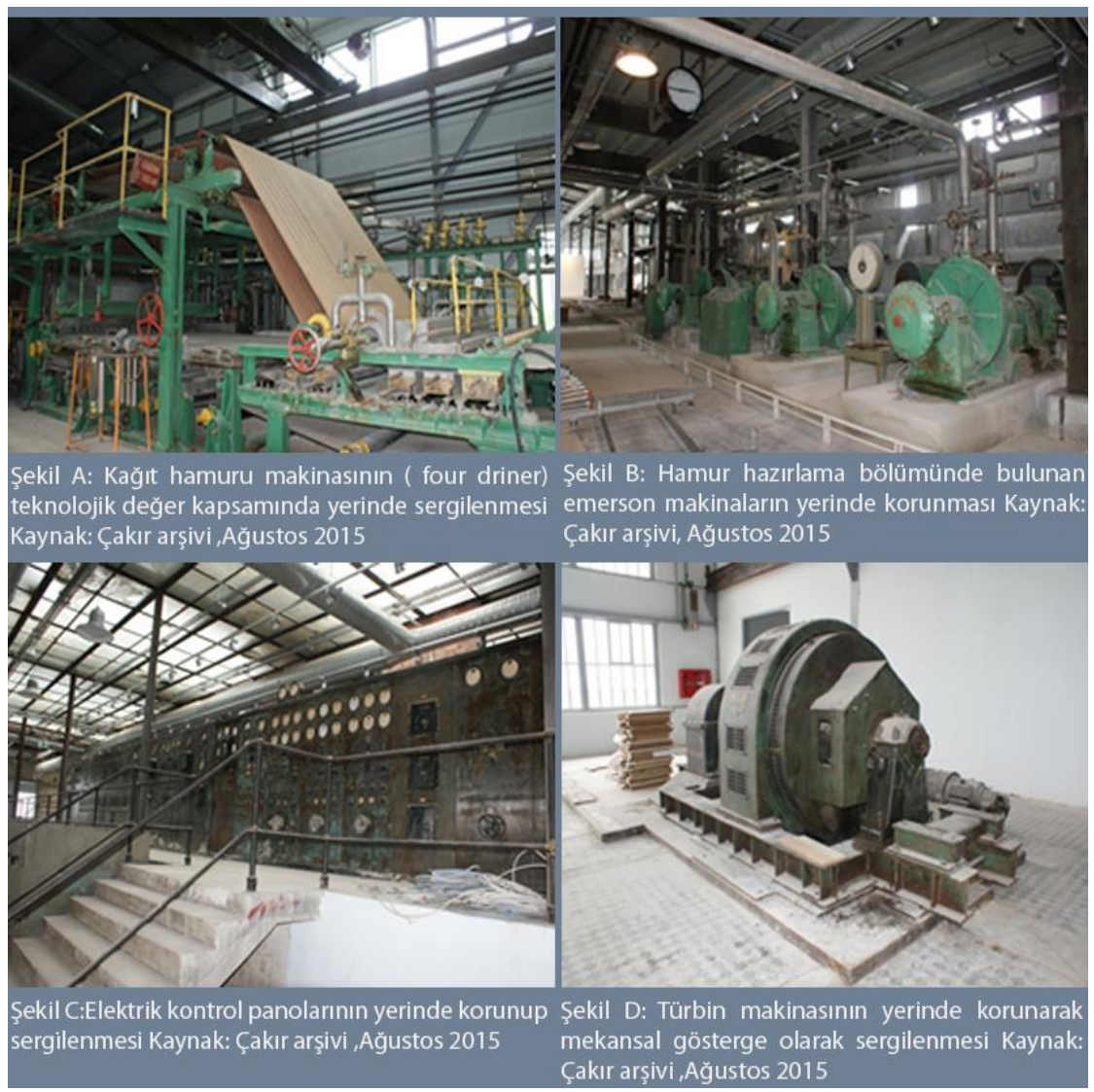

Şekil 5. SEKA Kağıt Müzesinde teknik ve teknolojik değer taşıyan göstergelerin korunmasi

Mekansal bellek göstergelerinin korunmasına ilişkin tasarım parametreleri açısından SEKA Selüloz ve Kağıt Fabrikasının dönüşümünün irdelenmesi, mekan tasarımına etki eden unsurların koruma açısından değerlendirilmesini gerektirmiştir.

Bağlam: Var oldukları sürece tarihi yapılar sahip oldukları değerlerle çevreleriyle ilişki içindedirler. Kullanım değerini sürdüren yapılarda işlevin etkisinde sürdürülen bu ilişki göstergeler üzerinden açığa çıkar. Bu göstergelerin korunmasıyla mekansal belleğin bağlamsal açıdan yansımaları tarihi yapılarda değer oluşturmaya devam edecektir. $\mathrm{Bu}$ yüzden yeniden işlevlendirilen tarihi bir yapıda mekan tasarımına etki eden parametreler ışığında bağlamın önemi göz ardı edilmemelidir. Bu konuda Yıldırım ve 
Güney'in aktardıkları dikkat çekicidir: “Kent belleği geçmişi bugünü ve geleceğe ait ipuçlarını içinde barındırır. Anıtlar, bazen bir sınır ögesi olarak duvar, bazen de bir bina, bugünden geçmişi hatırlatır ve kolektif belleğin taşıyıcıları olur. Kent anıtlarıyla yaşar ve hafızalara kaydedilir ', (Yıldırım, Güney, 2010;115). Kara, deniz ve demiryolu ulaşım aksının içinde bulunan SEKA Selüloz ve Kağıt Fabrikası konumu itibarıla bağlamsal olarak kentin nirengi noktalarındandır. Hammadde ihtiyacı için gerekli tomruğun fabrikaya ulaştırılabilmesi konumun belirlenmesinde belirleyici etkenlerin başında yer almıştır. SEKA Bölgesinin dönüşümünde önemli bir değer unsuru olan bu bağlamsal parametre dikkate alınarak yer - mekan ilişkisinin korunup yeni ulaşım akslarıyla desteklendiği görülmektedir. Böylelikle mekansal bellek bağlamsal açıdan korunarak geçmiş ve gelecek arasındaki bağ sağlıklı olarak kurulmuş olacaktır.

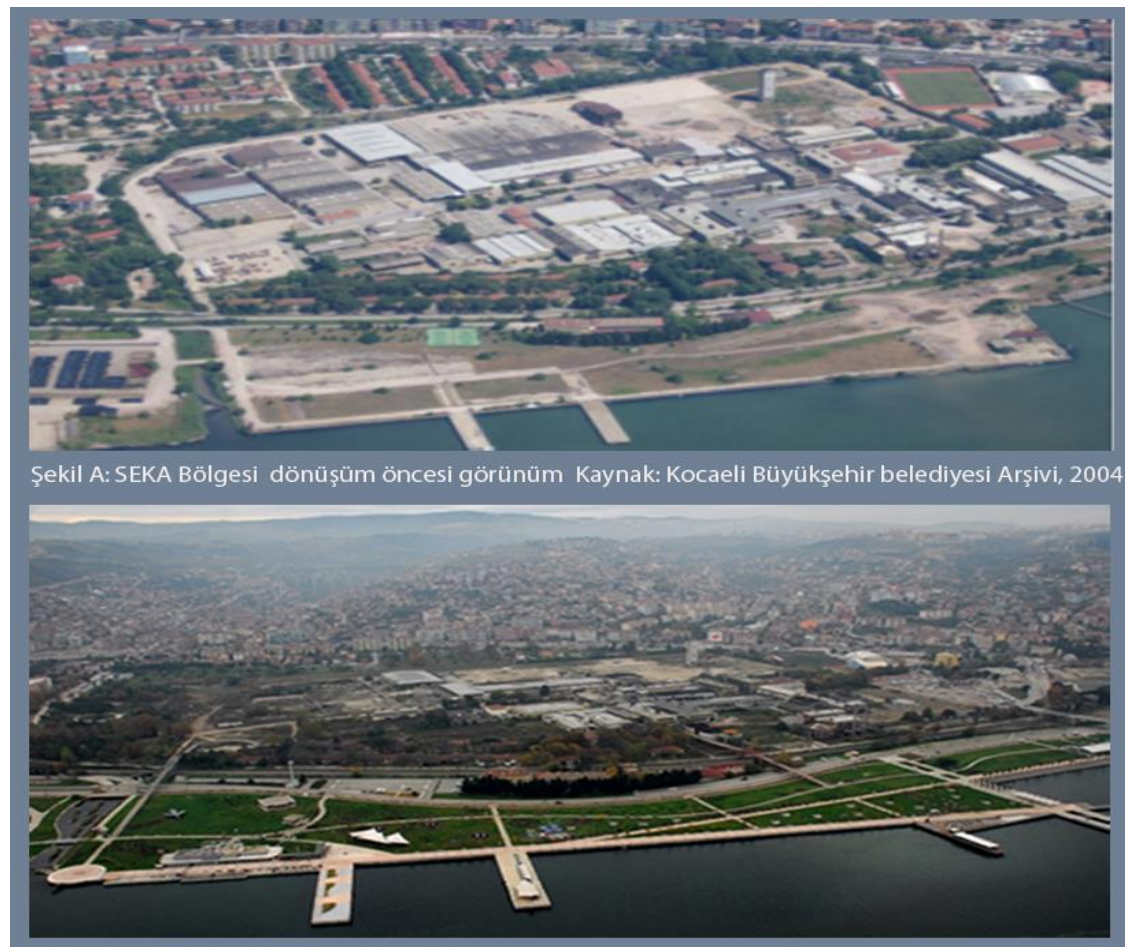

Şekil B: SEKA Bölgesi dönüşüm sonrası görünüm Kaynak: SEKA arşiv dokümantasyon merkezi,2008

Şekil 6. SEKA Bölgesi dönüşüm öncesi ve sonrası görünümü 
Yeni İşlevin Program ve Mekan Organizasyonuna Etkisi: Tarihi bir yapı işlevini yitirse de yeni bir işlevle varlığını sürdürebilir. Yeniden işlevlendirilen tarihi yapılarda yeni programın özgün mekansal kimliğe uygunluğu tasarım sürecindeki önemli kararların başında gelir. Belirlenen yeni program yapının fiziksel özelliklerinin yanı sıra mekansal belleğinin de korunması açısından önemlidir. Bu durumun bir örneği olarak; SEKA 1 Nolu Kağıt Fabrikasının Şekil 7'de görünen üretim akış şeması özgün mekan organizasyonu açısından önemli bir bilgi kaynağıdır. İşlevini değiştiren yapılarda yeni program bazı uygulamalarda başarılı olduğu gibi, mekanı zorlayan ve çevreyle uyumsuz sonuçlara da yol açabilmektedir. $\mathrm{Bu}$ yüzden yeni programın belirlenmesinde mekansal bellek göstergelerinin de varlığına dikkat edilmelidir.

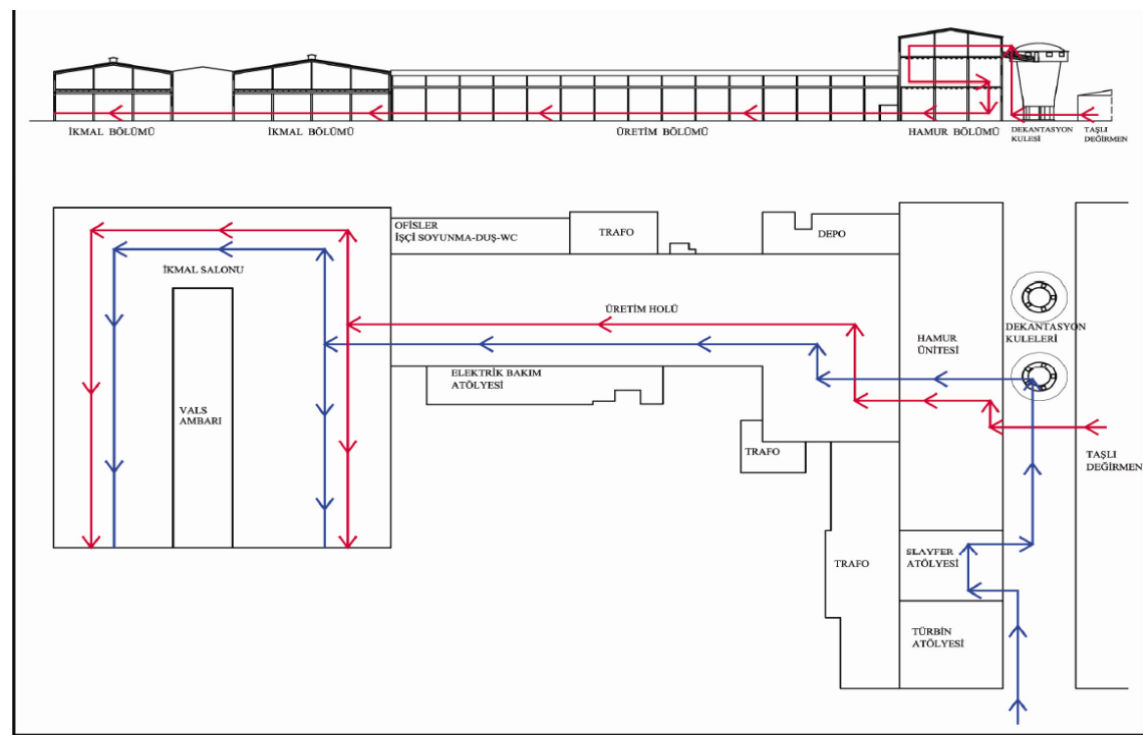

Şekil 7. SEKA 1 Nolu Kağıt Fabrikası üretim akış şeması Kaynak: SEKA arşiv dokümantasyon merkezi

Yeniden işlevlendirilen tarihi yapılarda mekan organizasyonu, özgünlük ve kullanım değerlerinin sürdürülmesi açısından önemli bir parametredir. Yeni işlev mekansal belleğe ilişkin göstergelerin değeri yok edilmeden planlanmalıdır. Yok edilen, kapatılarak 
gösterilmeyen veya önemini yitiren mekansal göstergeler, belleğin yitirilmesine ve yapının tarihi değerini kaybetmesine yol açacaktır.

İzmit Körfezindeki SEKA Selüloz ve Kağıt Sanayi Tesisi geçirdiği dönüşüm projesinin ardından Kağıt Müzesi ve Bilim Merkezi olarak hizmet verecektir. Yeni işlevin belirlemesinde SEKA Bölgesinin günün her saati kentli tarafindan çekim merkezi olması hedeflenmiştir. Birbirinden farklı işlevlerle desteklenen bu dönüşüm projesi, kağıt müzesi, bilim merkezi, etkinlik alanları, çağdaş park düzenlemesi, film platosu ve ofis birimleri, çeşitli kültür birimleri olarak her kesimden kitleye seslenmektedir.

Bölgedeki bu program değişikliği özgün işlevin mekansal yansımaları korunarak, mevzuatlara uygun müdahale yöntemleriyle gerçekleştirilmiştir. Böylelikle dönüşüm sonrası SEKA Bölgesi endüstriyel belleğin mekansal göstergeler üzerinden okunarak korunduğu yeni bir programlar bütünü ortaya çıkmıştır.

\section{Yapısal Bileșenlerde ve Mimari Elemanlarda Belleksel} Göstergeler: Tarihi yapılar mekansal bellek kapsamında değerlendirilirken yapısal bileşenleri ve mimari elemanlarıyla birlikte ele alınmalıdır. Bir yapının duvar, döşeme, kolon, kiriş, merdiven gibi yapısal bileşenleriyle mimari elemanları malzeme, biçim ve yapım teknikleri açısından mekansal belleğe ilişkin göstergelerdir (Şekil 8). Bu göstergeler korunarak mekansal belleğin bütünlük içinde sürekliliği sağlanmış olacaktır.

SEKA 1 Nolu Kağıt Fabrikası mekansal belleğini yapısal bileşenler ve mimari elemanların oluşturduğu göstergeler aracılığıyla korumaktadır. Fabrika dönüşüm sürecinde yapı için karakteristik anlam taşıyan servis asansörü, kapı, özgün döşemeler korunmuştur. $\mathrm{Bu}$ durum yapının mekansal belleğinin göstergeler üzerinden okunması ve korunması bakımından önemli bir yaklaşımdır. 


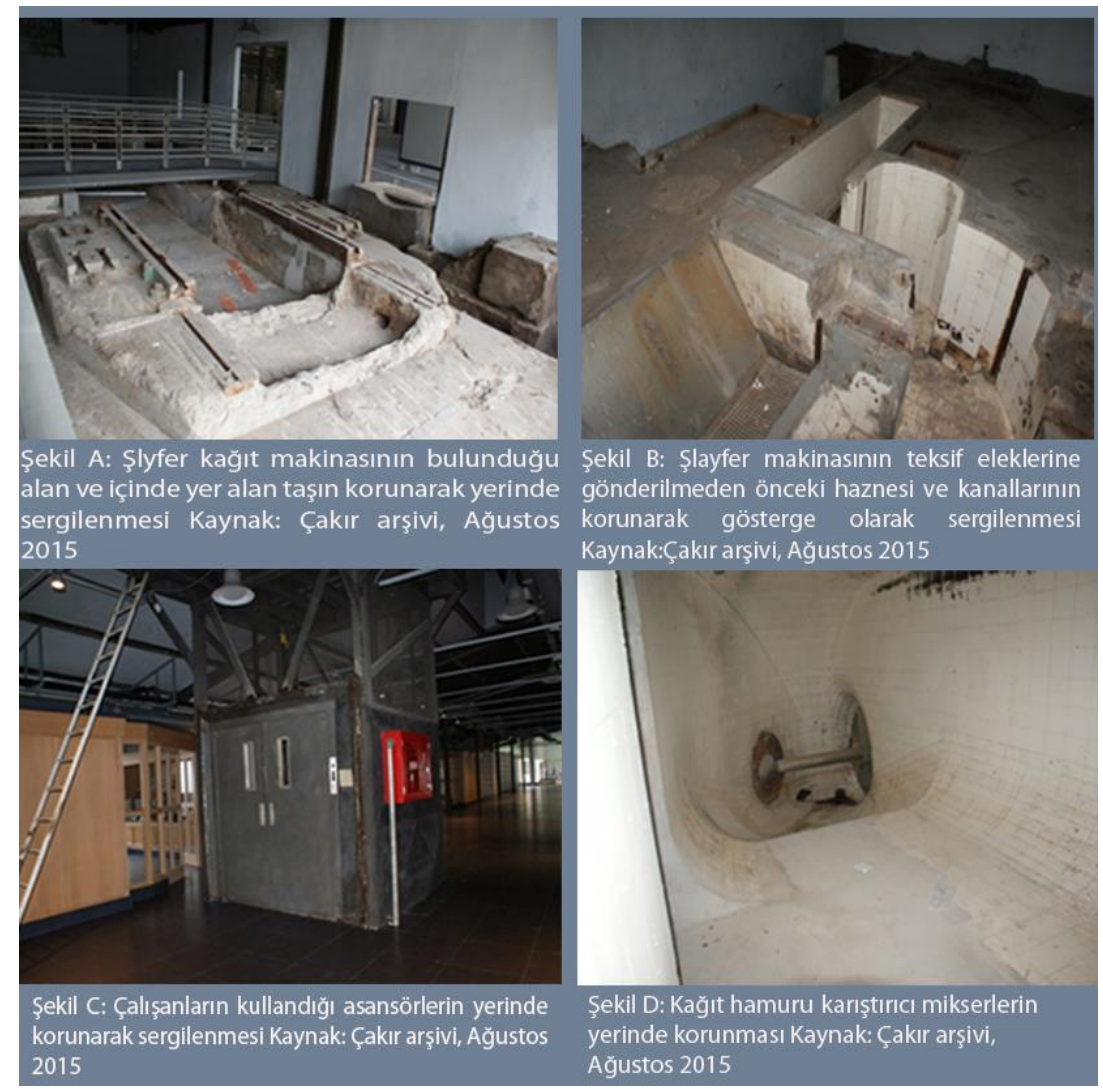

Şekil 8. Dönüşüm sonrası SEKA Kağıt Müzesinde mekansal belleğin göstergesi olan özgün elemanlar

\section{İç Mekan Donatı Elemanları (Hareketli - Hareketsiz):}

Endüstriyel mirası korumaya yönelik TICCIH Tüzügüünün 2. Maddesinde yer alan "Endüstri mirasın kendi yerinde korunmasına öncelik verilmelidir.' ifadesine göre SEKA 1 Nolu Kağıt Fabrikasının özgün iç mekan donatı elemanları, müze ve bilim merkezine dönüşen yapıda yerinde korunarak sergilenmektedir. Vinç, fabrika makine parçalarının bulunduğu izler, kağıt hamuru havuzları, tomrukların taşınması için kullanılan raylar gibi mekanik donatıların restore edilerek çalışır vaziyette özgün yerlerinde sergilenmesi mekansal bellek göstergelerinin ortaya çıkarılması ve korunması bakımından olumlu bir yaklaşımdır. Mekanik donatıların yanı sıra Şekil 9'da görülen ahşap dolaplar ve kesim masası SEKA'nın mekansal belleğine 1şık tutan diğer göstergelerdir. Gerek 
hareketli, gerekse hareketsiz donatılar bütüncül bir anlayışla korunarak fabrikanın üretim akışını ortaya çıkararak endüstri yapısının nasıl işlediğine yönelik bilgi oluşturmaktadır.

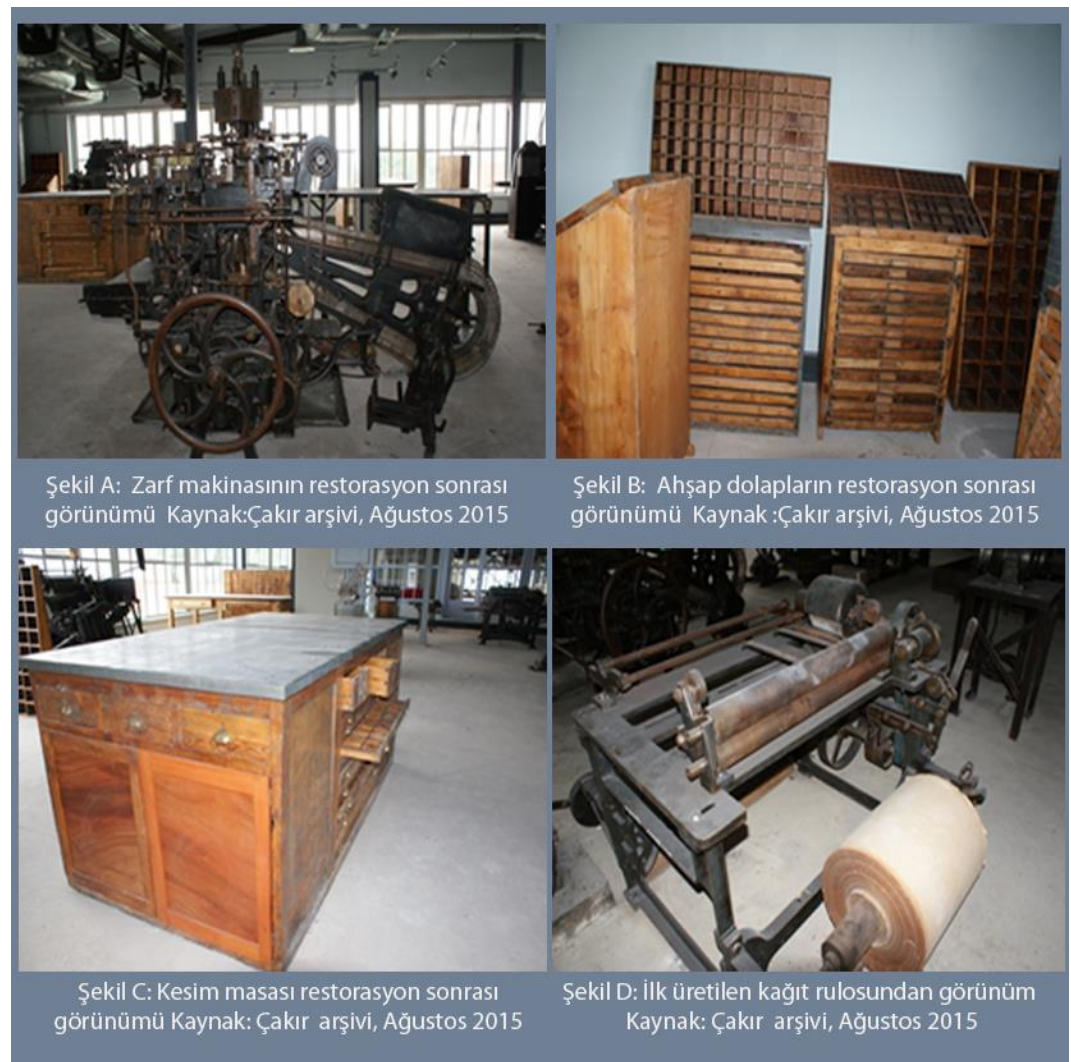

Şekil 9. SEKA Kağıt Müzesindeki donatı elemanlarının bellek göstergesi olarak sergilenmesi

Malzeme Seçimi: Yeniden işlevlendirilen tarihi yapılarda yapısal ve mekansal ihtiyaçlar yeni malzeme kullanımını gerektirebilir. Yeni malzeme seçimi mekansal belleğe ilişkin göstergelerin okunmasında önemli rol oynar. Bir tasarımcı tercih ettiği malzemeyle, mekansal belleğe ilişkin göstergeleri ön plana çıkartabileceği gibi geri plana da itebilir. Bu konuda birçok farklı görüş bulunmaktadır. Tarihi yapıdakiyle aynı ya da benzer malzeme seçim yaparak, mekanla zıtlaşmak istemeyen tasarımcılar olduğu gibi, modern bir anlayışla mekanın tarihi dokusundan farklı malzemeler de tercih edilebilir. 
SEKA Kağıt Müzesi ve Bilim Merkezinde sonradan yapılan eklentilerin ve kullanılan malzemelerin modern ve ayırt edilebilir nitelikte olduğu görülmektedir. $\mathrm{Bu}$ malzeme seçimiyle tarihin katmanlar halinde ayırt edilebilmesi mekansal belleğin göstergelerinin okunabilmesi bakımından önemlidir. Yapılan eklentiler modern ve minimalist bir anlayışla tarihi yapıyla yarışmayan biçimde tasarlanmıştır. İç mekanda sergilemeye dönük yeni ekler hafif ve tarihi yapıya minimum düzeyde zarar verecek şekilde uygulanmıştır (Şekil 10). Bu koruma yaklaşımı ve malzeme seçimi mekansal bellek göstergeleri kapsamında değerlendirilirse; özgünlük ve kullanım değerinin sürekliliği bakımından başarılı sonuçlar elde edilmiştir.

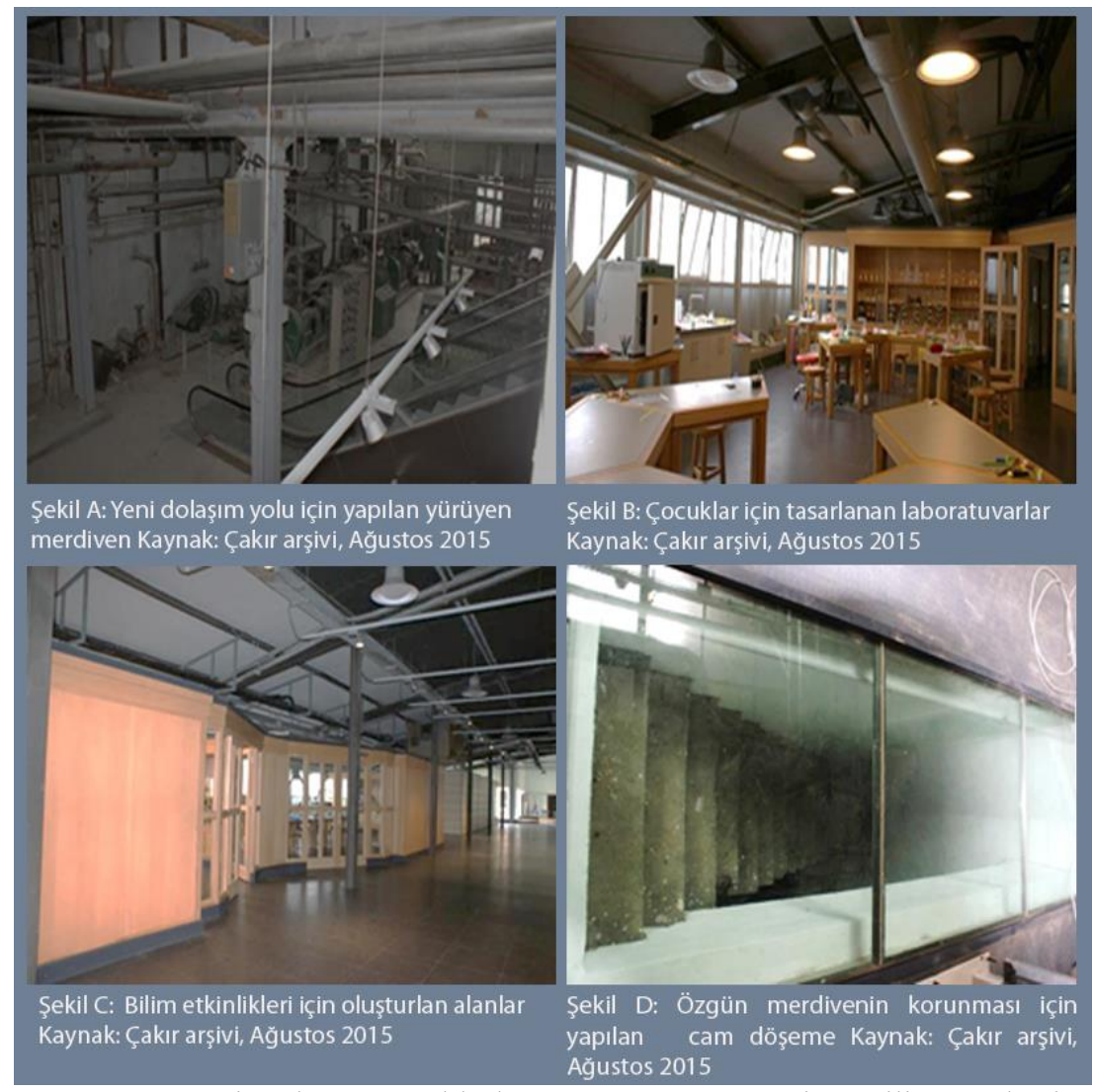

Şekil 10. Yeni malzeme ve eklerle SEKA Kağıt Müzesi ve Bilim Merkezi 
Aydınlatma: Işık kullanımı mekanda görsel ve algısal alarak kullanıcıyı etkiler. Yapay aydınlatma ve doğal ışı̆̆ın kullanımı tarihi yapılarda mekansal göstergelerin doğru ifade edilmesi açısından önemlidir. Yeniden işlevlendirilen birçok tarihi yapıda yaygın bir tasarım anlayışı olarak mekansal bellek göstergeleri yapay aydınlatma ile ön plana çıkarılmak istenmektedir. Bu tasarım anlayışında yer yer yapay 1şığın renk unsuru ile bir arada kullanılarak vurguyu arttırdığı da görülmektedir. Müze yapılarında ışık kullanımı çok önemlidir. Müzeye dönüştürülen 1 Nolu SEKA Kağıt Fabrikasının özgün aydınlatma tasarımı ve pencere açıklıklarının korunmasının yanı sıra sergileme ve yönlendirme esasına dayalı yeni eklenen aydınlatma tasarımı da bulunmaktadır. Korunan doğal aydınlatma ve özgün elemanların ön plana çıkarılması için oluşturulan noktasal aydınlatma mekansal belleğin göstergelerine katkı sağlamıştır.

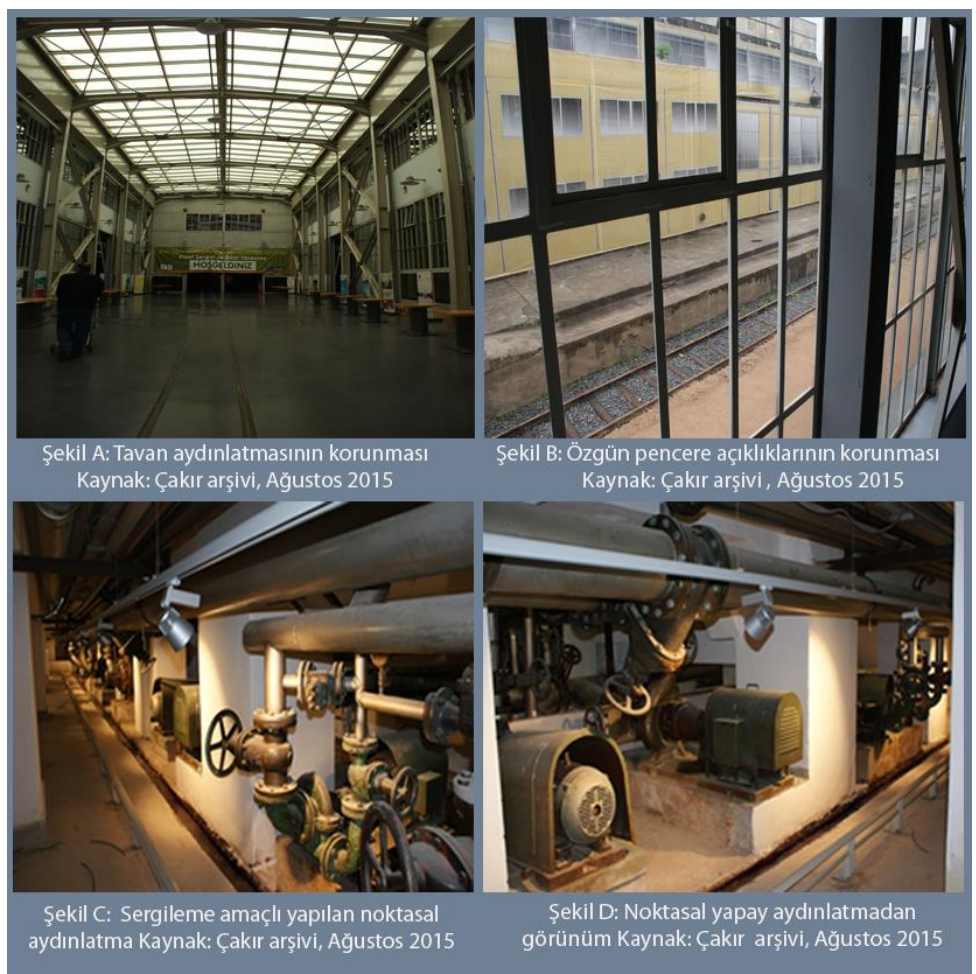

Şekil 11. SEKA Kağıt Müzesi ve Bilim Merkezinin aydınlatma yönünden incelenmesi 


\section{SONUÇ VE DEĞERLENDİRME}

Tarihi yapıların korunması konusundaki kararlar mekan ve bellek ilişkisinin ortaya çıkarılmasını gerektirmektedir. Göstergeler üzerinden kurulan mekan-bellek ilişkisinin kullanıcının algısına ve mekansal deneyimine dayalı olduğu söylenebilir. Buna göre; mekan ve bellek ilişkisi hatırlama ve bellekten çağırma durumunun etkisiyle kişiden kişiye farklılık gösterebilir. Başkası için anlam taşıyan göstergeler, diğer kullanıcılar için bir şey ifade etmeyebilir.

Tarihi yapılar sahip olduğu değerleri koruyabildikleri sürece geleceğe sağlıklı bilgi aktarabilirler. Mekansal bellek kavramı bu değerleri ortaya çıkaran önemli bir faktördür. Fiziksel nitelikleriyle birlikte bir bütün olarak korunması gereken tarihi yapıların sahip olduğu değerlerin ortaya çıkarılmasında mekansal belleğe ilişkin göstergelerin önemli bir yeri vardır. Tarihi yapılarda mekansal bellek göstergeler üzerinden okunarak bilgiye dönüşür. Göstergeler aracılığıyla ulaşılan her bilgi tarihi yapılar için ayrı bir değer anlamına gelir. Anı, kullanım, tarihi, kültürel, vb. tüm değerler bütüncül bir anlayışla göstergeler aracılığıyla korunarak tarihi yapılarda mekansal belleğin sürekliliği sağlanmış olur.

Tarihi yapılar ayakta kalabilmek için müdahale gerektirebilir. Bu müdahalelerde mekansal göstergeler korunarak açığa çıkarılmalıdır. Yanlış uygulamalarla kapatılan ya da yok olan her gösterge tarihi yapının değerinden bir kayıp demektir. Bu yüzden tarihi yapılardaki müdahaleler uzman kişiler tarafından gerçekleştirilmelidir.

Bu çalışma konusu kapsamında örnek olarak SEKA Selüloz ve Kağıt Fabrikasının, Kağıt Müzesi ve Bilim Merkezine dönüşümü irdelenmiştir. Yeniden işlevlendirilen tarihi yapının mimari dönemsel kimliği, özgünlük, estetik ve anı değerleri göstergeler üzerinden korunarak mekansal bellekteki süreklilik sağlanmıştır. SEKA'nın yeniden işlevlendirme ile gündeme gelen program değişikliği mekansal bellek göstergelerinin bilgi aktarmasının önemini ortaya koymaktadır. Müze ve bilim merkezine dönüştürülen 
SEKA Selüloz ve Kağıt Fabrikası, bir endüstri mirası olmasının yanı sıra işlevini yitirmiş diğer tarihi yapıların korunması açısından da mekansal bellek göstergelerinin önemine dikkat çekmektedir.

Günümüzde sanayi yapıları bulundukları kente kattıkları sosyo kültürel değer bakımından önemlidir. SEKA Selüloz ve Kağıt Fabrikası da bulunduğu kentin belleğinde önemli bir göstergedir. Kolektif bellek olarak değerli bir gösterge olan bu yapının yeniden işlevlendirilerek bölgeye kazandırılması tarihsel sürekliliğin korunması bakımından önemlidir.

\section{KAYNAKLAR}

[1] Bergson, H., (1998). Metafiziğe Giriş, Çev. Barış Karacasu, Bilim ve Sanat Yayınları, Ankara.

[2] Cevizci, A., (1996). Metafiziğe Giriş, Paradigma Yayını

[3] Feilden, B. M., ( 2003). Conservation of historic buildings. ( Third edition). Oxford: Elsevier.

[4] Hançerlioğlu, O., ( 2012) . Felsefe Sözlüğü, 20. Bask1, Remzi Kitabevi, İstanbul

[5] Heidegger, Martin., (1997). Zaman Kavramı, İstanbul: Cogito, Sayı: 11

[6] Huyssen, A., (1995). Twilight Memories, Making Time in a Culture of Amnesia. Routledge. New York.

[7] Olick, J., (1999). "Collective Memory: The Two Cultures." Sociological Theory 3(17): 333-348

[8] Rossi, A., (2006). Şehrin mimarisi, Kanat Kitap, İstanbul. Çev. Nurdan Gürbilek

[9] Ruskin, J., (1849). The Seven Lamps of Architecture

[10] Yıldırım, S., (1996). Kentsel \& Mekansal Yapı Çözümlemesi - Kent Oluşum Kuramları \& Kent Çözümlemesinde Temel Dizgeler. Edirne Kent Kurgusu \& Mekansal Yapı Çözümlemesi, Gazi Üni. İletişim Fak. Basımevi, Ankara 
[11] Yıldırım, S. \& Güney, D., (2010). İstanbul Kent Belleği ve Mekansal Süreklilik, FSF Print HOUSE, Çev. Doç Dr. Ferma Lekesizalın, Zeynep Yıldırım

\section{[12]URL 1}

http://images.beyazgazete.com/haber/2011/7/1/20110701_tarihicamiyi-vincle-tasidilar_k.jpg (Erişim tarihi: 20.04.2015)

[13] URL 2 http://www.pazar53.com/186-yillik-ahsap-cami-tasindi18527h.htm (Erişim tarihi: 20.04.2015)

\section{[14] URL 3}

http://www.haberci53.com/images/upload/h\%C3\%BCseyin\%20hoca \%20cami\%20tarihi.jpg (Erişim tarihi: 20.04.2015)

\section{[15] URL 4} http://www.rize.gov.tr/ortak_icerik/rize/galeri//124/IMG_4828.jpg (Erişim tarihi: 20.04.2015) 